BIOKEMISTRI 17(2):95-99 (Dec 2005)

Available online at http://www. bioline.org. br/bk.

Abstracted online at www.ajol.info/journals/biokem

Printed in Nigeria

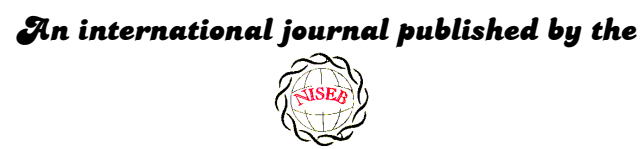

OVigerian \&ociety for \&ิxperimental ßiology

\title{
Antitrypanosomal and haematological effects of selected Nigerian medicinal plants in Wistar rats
}

\author{
Abdulkadir ABUBAKAR ${ }^{* 1}$; Binta ILIYASU ${ }^{1}$; Aminu B. YUSUF ${ }^{1}$; Augustine C. IGWEH $^{1}$; \\ Nnennaya A. ONYEKWELU ${ }^{1}$; Bala U. SHAMAKI ${ }^{2}$; David O. AFOLAYAN ${ }^{3}$; Emmanuel 0. \\ OGBADOYI ${ }^{4}$ \\ ${ }^{1}$ Biochemistry and Chemotherapy Division, ${ }^{2}$ Veterinary and Livestock Studies Division, \\ ${ }^{3}$ Parasitology Section, Nigerian Institute for Trypanosomiasis Research, P.M.B. 03, Vom, \\ Plateau State, Nigeria. \\ ${ }^{4}$ Biochemistry Department, Federal University of Technology, Minna, Niger State, Nigeria
}

Received 9 July 2005

MS/No BKM/2005/033, @ 2005 Nigerian Society for Experimental Biology. All rights reserved.

\begin{abstract}
Studies to determine the effect of some Nigerian Medicinal plants on some haematological parameters of rats infected with $T . b$. brucei was carried out. The plants investigated and the dose levels per kilogram body weights used are fresh Momordica balsamina pulp (150mg); fresh Aloe vera pulp (1ml); aqueous extracts of Securidaca longipenduculata root and root bark (100mg) and Annona senegalensis leaves (200mg). All the animals were treated orally for seven consecutive days after establishment of parasitaemia. Parasitaemia and some haematological parameters were determined before and after treatment as well as pathochemical composition of each plant. The result showed a significant $(\mathrm{P}<0.05)$ improvement in Packed Cell Volume $(\mathrm{PCV})$ values of rats treated with $M$. balsamina; A. vera and S. longipenduculata (root bark) when compared with the positive control. Total leukocyte and lymphocyte counts did not change significantly $(\mathrm{P}>0.05$ ) in groups treated with $M$. balsamina and $S$. longipenduculata (root bark) but increased in other treated and positive control groups. Similarly, no significant changes $(\mathrm{P}>0.05)$ in neutrophils was observed in M. balsamina and S. longipenduculata (root) treated animals but an increase was seen in S. longipenduculata (root bark), A. vera and infected on treated groups. Treatment with $M$. balsamina, A. vera and S. longipenduculata (root and root bark) prolonged the lives of animals by 4, 1, 3 and 4 days respectively when compared with the positive control. Differences in the composition of various phytochemical of these plants could be responsible for the varied antitrypanosomal activities. Consequently, these plants have great potential which need to be exploited fully in the management of African trypanosomiasis.
\end{abstract}

Key words: Medicinal Plants, Haematological Parameters, T.b. brucei.

*Author to whom all correspondence should be addressed.

E-mail: yaisah2002@yahoo.com; Tel: 08035895490 


\section{INTRODUCTION}

The more important trypanosome species affecting man and his domestic animals have been subdivided into two groups, the haematinic group (Trypanosoma congolense, $T$. vivax) which remains in the plasma and the tissue invading group (T. brucei, T. evansi, $T$. gambiense, T. rhodesiense and T. equiperdum) which is found extravascularly and intravascularly ${ }^{1}$. Because of their presence in the blood, they produce numerous changes in the cellular and biochemical constituents of blood.

Chemotherapy and chemoprophylaxis, which form the most important and major aspect of the control and eradication of Trypanosomiasis in African countries is beset with problems. These include limited repertoire of compounds, resistance to drugs, drug toxicity and protracted treatment protocol ${ }^{2}$. According to the world health organization, more than $80 \%$ of the world population still rely on herbal medicines as their primary source of health care. Millions of Africans of all ages rely on herbal medicine for primary health care ${ }^{3}$. Plants have provided the basis for traditional treatment for different types of disease and still offer an enormous potential source of new chemotherapeutic agents. In northern Nigeria, where this disease is prevalent, traditional healers used medicinal plants either singly or in combination in the treatment of different types of disease particularly Trypanosomiasis ${ }^{4}$.

This study was therefore initiated with a view to determining the effect of some medicinal plants in alleviating the cellular changes produced during the T. $b$. brucei infections of rats. Plants selected for this investigation included Momordica balsamina pulp, Aloe vera pulp, Annona senegalensis, Securidaca longipenduculata root and root bark. They were claimed to possess antiprotozoal activity and alleviate one or many of the clinical symptoms such as intermittent fever, immunosuppression, anaemia, jaundice and hepatomegaly commonly associated with trypanosomiasis 5 .

\section{MATERIALS AND METHODS \\ Animal and parasite}

Adult white albino rats of mixed sex weighing between $120-150 \mathrm{~g}$ were purchased from the small animal breeding unit of Parasitology section, Nigerian Institute for Trypanosomiasis Research, Vom and Trypanosoma brucei brucei was isolated from cattle in Lafia, Nasarawa State of Nigeria. The parasites were maintained by serial passage in rats in veterinary and Livestock Studies Division, NITR, Vom.

\section{Plant collection}

Momordica balsamina and Aloe vera were collected in the months of January in K-Vom, Jos South LGA of Plateau State while Securidaca longipenduculata root and Annona senegalensis were collected from Bida and Bosso respectively, Niger State in March. All the plants were obtained with the help of traditional healers. They were all authenticated by Mallam Abdulkarim of Federal College of Forestry, Jos, Plateau State, Nigeria where voucher specimen has been deposited.

\section{Preparation of plant extracts}

The M. balsamina apple was cut into two and the fresh pulp containing the seeds squeezed out. The seeds were separated from the pulp using a wire mesh. Aloe vera pulp was also obtained after cutting the plant longitudinally into two. The root and separated root bark of $S$. longipenduculata and leaves of $A$. senegalensis were air dried at room temperature. All these were then separately reduced to coarse forms using a mortar and pestle. The $S$. longipenduculata (root and root bark) and leaves of $A$. senegalensis were slowly evaporated to dryness on a hot water bath, to give a concentration of $50 \mathrm{mg} / \mathrm{ml}$ dry matter.

\section{Phytochemistry}

The phytochemistry analysis of the plant extracts was carried out as described by Odebiyi and Sofowora $^{6}$ to test for the presence of tannins, resins, glycosides, flavonoids, alkaloids and saponins.

\section{Experimental design}

The rats were divided into 7 groups (A- G) of 5 animals each. Groups A-F rats were each inoculated with $1 \times 10^{6} \mathrm{~T}$. b. brucei in $0.2 \mathrm{ml}$ normal saline. With the establishment of parasitaemia, animals in groups A-E were respectively treated orally for 7 consecutive days 
at different dose levels per $\mathrm{kg}$ body weight as follows: M. balsamina pulp $(150 \mathrm{mg} / \mathrm{kg})$. A. vera pulp $(1 \mathrm{ml} / \mathrm{kg})$. A. senegalensis $(200 \mathrm{mg} / \mathrm{kg})$, $S$. longipenduculata root and root bark $(100 \mathrm{mg} / \mathrm{kg})$. Blood samples were collected before and after treatment from the tail end of each rat for the determination of packed cell volume (PCV) total and differential leucocyte counts. Parasitaemia was determined and estimated daily by the method of Herbert and Lumsden $^{7}$.

\section{RESULTS}

The results of phytochemical screening are presented in Table II while effect of the extracts on PCV, Total and Differential leucocyte counts are presented in Table 1. Increase in PCV was observed in all the treated animals, with $M$. balsamina having the highest value when compared with infected, untreated control. With the exception of $M$. balsamina, and $S$. longipenduculata (root bark) treated group, leucocytosis and lymphocytosis was observed in other treated and untreated groups. Neutropaenia was also observed in $A$. vera, $S$. longipenduculata (root), A. senegalensis treated groups and infected untreated control while increase was seen in $S$. longipenduculata (root bark) treated group. No significant changes was seen in $M$. balsamina treated group and uninfected, untreated control $(\mathrm{P}>0.05)$. However changes in monocytes and eosinophils were inconsistent. The phytochemicals present high in concentration in the extracts are alkaloids and Tannins (A. vera); glycoside (M. balsamina); alkaloids, flavonoids and Saponins ( $S$. longipenduculata root) and tannins in $A$. senegalensis.

Table 1: Effect of Extract of Some Medicinal Plants on Some haematological parameters in Rats infected with $T$. b. brucei

\begin{tabular}{|c|c|c|c|c|c|c|}
\hline Plants & $\operatorname{PCV}(\%)$ & $\begin{array}{c}\text { TLC } \\
\left(\times 10^{3}\right)\end{array}$ & Lymphocytes & Neutrophils & $\begin{array}{l}\text { Parasitaemia } \\
\qquad\left(\times 10^{6} \mathrm{ml}\right)\end{array}$ & $\begin{array}{c}\text { Survival } \\
\text { (Days) }\end{array}$ \\
\hline A. vera & $\begin{array}{l}+43.0 \pm 4.4 \\
++37.0 \pm 0.5^{\mathrm{a}}\end{array}$ & $\begin{array}{l}7.7 \pm 0.2 \\
9.1 \pm 0.8\end{array}$ & $\begin{array}{l}67.3 \pm 3.8^{\mathrm{d}} \\
75.0 \pm 7.2^{\mathrm{e}}\end{array}$ & $\begin{array}{l}31.7 \pm 4.1^{\mathrm{f}} \\
21.0 \pm 2.0^{\mathrm{g}}\end{array}$ & $\begin{array}{l}0.45 \pm 005 \\
228.02 \pm 23.2\end{array}$ & $8-10(1)$ \\
\hline M. balsamina & $\begin{array}{l}42.5 \pm 0.5 \\
39.0+1.0^{\mathrm{a}}\end{array}$ & $\begin{array}{l}9.3+0.4^{\mathrm{c}} \\
8.3+1.1^{\mathrm{c}}\end{array}$ & $\begin{array}{l}74.0+5.3 \\
73.0+6.2\end{array}$ & $\begin{array}{l}28.5 \pm 0.5 \\
30.0 \pm 2.0\end{array}$ & $\begin{array}{l}0.30 \pm 0.1 \\
94.81 \pm 7.9\end{array}$ & $10-13(4)$ \\
\hline $\begin{array}{l}\text { A. } \\
\text { senegalensis }\end{array}$ & $\begin{array}{l}42.5 \pm 0.5 \\
35.5 \pm 2.1\end{array}$ & $\begin{array}{l}6.2 \pm 1.2 \\
11.4 \pm 0.9\end{array}$ & $\begin{array}{l}62.0 \pm 3.0^{\mathrm{d}} \\
72.5 \pm 0.5^{\mathrm{e}}\end{array}$ & $\begin{array}{l}33.5 \pm 3.5 \\
26.5 \pm 2.1\end{array}$ & $\begin{array}{l}0.49 \pm 0.08 \\
324.65 \pm 73.5\end{array}$ & $8-9(0)$ \\
\hline $\begin{array}{l}\text { S. } \\
\text { longipenducul } \\
\text { ata (root) }\end{array}$ & $\begin{array}{l}42.5 \pm 0.5 \\
35.5 \pm 2.1\end{array}$ & $\begin{array}{l}6.7 \pm 0.7 \\
11.0 \pm 2.0\end{array}$ & $\begin{array}{l}66.5 \pm 2.1 \\
70.0 \pm 2.8\end{array}$ & $\begin{array}{l}33.5 \pm 2.1 \\
29.0 \pm 1.4\end{array}$ & $\begin{array}{l}0.38 \pm 0.1 \\
188.55 \pm 62.7\end{array}$ & $8-12(3)$ \\
\hline $\begin{array}{l}\text { S. } \\
\text { longipenducul } \\
\text { ata (root bark) }\end{array}$ & $\begin{array}{l}43.7 \pm 4.5 \\
37.5 \pm 1.5^{\mathrm{a}}\end{array}$ & $\begin{array}{l}6.7 \pm 0.8^{\mathrm{c}} \\
7.0 \pm 0.7^{\mathrm{c}}\end{array}$ & $\begin{array}{l}66.0 \pm 9.5 \\
67.3 \pm 5.8\end{array}$ & $\begin{array}{l}28.5 \pm 0.5^{\mathrm{f}} \\
35.0 \pm 1.0^{\mathrm{g}}\end{array}$ & $\begin{array}{l}0.30 \pm 0.1 \\
188.24 \pm 30.7\end{array}$ & $9-13(4)$ \\
\hline $\begin{array}{l}\text { Infected, } \\
\text { untreated }\end{array}$ & $\begin{array}{l}42.0 \pm 1.0 \\
29.5 \pm 0.5^{b}\end{array}$ & $\begin{array}{l}6.2 \pm 0.3 \\
10.2 \pm 0.7\end{array}$ & $\begin{array}{l}60.7 \pm 4.7^{\mathrm{d}} \\
71.7 \pm 6.0^{\mathrm{e}}\end{array}$ & $\begin{array}{l}39.0 \pm 4.3^{\mathrm{f}} \\
25.5 \pm 3.5^{\mathrm{g}}\end{array}$ & $\begin{array}{l}0.57 \pm 0.07 \\
449.65 \pm 51.6\end{array}$ & $8-9$ \\
\hline $\begin{array}{l}\text { Uninfected, } \\
\text { untreated }\end{array}$ & $\begin{array}{l}41.5 \pm 0.5 \\
39.5 \pm 0.5\end{array}$ & $\begin{array}{l}8.7 \pm 0.5 \\
9.0 \pm 1.5\end{array}$ & $\begin{array}{l}74.6 \pm 0.9 \\
76.7 \pm 1.5\end{array}$ & $\begin{array}{l}25.0 \pm 1.2 \\
22.7 \pm 0.6\end{array}$ & - & - \\
\hline
\end{tabular}

Key: $T L C=$ Total leucocyte count; $P C V=$ Packed cell volume; +=Pretreatment; $++\quad=$ Post treatment; $a, b, d, e, f, g=$ mean $\pm S D$ with different superscripts are significantly different $(P<0.05)$ while $c$ are not significant $(P>0.05)$. 
Table 2: $\quad$ The Phytochemical Composition of the Plants Extracts

\begin{tabular}{|c|c|c|c|c|c|c|}
\hline \multirow[b]{2}{*}{ Plant extracts } & \multicolumn{6}{|c|}{ Phytochemicals } \\
\hline & Tannin & Resins & Alkaloids & Glycosides & Flavonoid & Saponins \\
\hline A. vera & +++ & ++ & +++ & + & + & - \\
\hline M. balsamina & - & + & - & +++ & + & + \\
\hline A. Senegalensis & +++ & - & - & ++ & + & - \\
\hline $\begin{array}{l}\text { S. longipenduculata } \\
\text { (root) }\end{array}$ & - & - & +++ & - & +++ & +++ \\
\hline $\begin{array}{l}\text { S. longipenduculata } \\
\text { (root bark) }\end{array}$ & - & - & ++ & - & ++ & ++ \\
\hline
\end{tabular}

Key: $+++=$ Highly present,$++=$ moderately present,$+=$ faintly present,$-=$ not present

\section{DISCUSSION}

The result of this study showed that these plants investigated have potential in the management of African Trypanosomiasis due to T. $b$ brucei. Momordica balsamina and S. longipenduculata has the highest potential since they are able to control anaemia by resisting sudden drop in PCV values. Earlier studies have shown $S$. longipenduculata to induce Anaemia at higher dosage $^{8}$ probably due to its high saponin contents. However, at low dose level, we also observed reduction in parasitaemia and consequent prolongation of life. It has been established that the measurement of anaemia gives a reliable indication of the disease status ${ }^{9}$ and productive performance ${ }^{10}$ of trypanosome infected animals.

Reports of leucocytosis due to lymphocytosis are shown at the onset of trypanosomiasis while leucopaenia is always seen at terminal stage of the infection ${ }^{11}$. These are usually due to wax and wear syndrome on the animal immune system caused by the ever changing variable surface glycoprotein of the infecting trypanosomes. However, the administration of M. balsamina pulp and $S$. longipenduculata prevented leucocytosis due to lymphocytosis thus prolonging the survival of the rat beyond the death of the infected, untreated control.

Several mechanisms such as granulocyte hypoplasia and splenic sequestration have been proposed for neutropaemia in African Trypanosomiasis ${ }^{11}$. It has been suggested that granulocyte progenitor cells may be coated with trypanosome antigen-antibody as occurred with

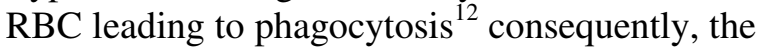
effect of $M$. balsamina and S. longipenduculata (root bark) on the reduced parasite load as seen in this studies, may led to a decrease in coating of the progenitor cells resulting to improvement in neutropaenia when compared with other treated groups and infected, untreated group. Furthermore, these observations have led to prolongation of lives of $M$. balsamina, A. vera and $S$. longipenduculata (root and root bark) treated animals by $4,1,3$, and 3 days respectively. Different phytochemical present in these plants could be responsible for the varied antitrypanosomal activities. There is therefore a need for further extensive work on these plants using different parasite species, at higher dosages, different routes of administration and possible combinations in order to exploit their full potential in the management of African trypanosomiasis. In addition, these plants should be sourced from different geographical locations. This is because the existence of different variants, soil and climatic conditions affect phytochemical constituents and hence the therapeutic actions of the same plant ${ }^{6}$.

\section{Conclusion}

Treatment of $T . \quad b$ brucei infected rats with $M$. balsamina; A vera and $S$. longipenduculata (root bark) resulted to improvement in PCV, while 
total leucocyte, neutrophils and lymphocytes count did not change significantly. These plants also prolonged the lives of animals beyond untreated control. Consequently, they are potentials in the management of African trypanosomiasis.

\section{REFERENCES}

1.Losos, G. J. and Ikede, B. O., (1972) Review of the pathology of domestic and laboratory animals caused by $T$. congolense, $T$. vivax, T. brucei. T. rhodesiense and T. gambiense. Vet. Path.; 9:1-71.

2. TDR (1984) Tropical Disease Research, $7^{\text {th }}$ programme report $1^{\text {st }}$ January, $1984-31^{\text {st }}$ December 1984. Chapter 5, 3-9. United Nations Development Programme/world bank/ world health organization.

3.McCaleb, R. (2000) McCaleb's Traditional Medicine Agenda added to National Plan of Action for Africa. A SNAPP UNDATA 8, ASNAPP NEWS.

4.Igweh, A. C and Onabanjo, A. O. (1989) Chemotherapeutic effects of Annona senegalensis in T. b. brucei. Ann. Trop. Med. Parasitol. 83:527-534.

5.Burkill, H.W (1985). The useful plants of West Tropical African Vol 1 pp.594-601.
6. Odebiyi, O.O. and Sofowora .E. A (1978) Phytochemical screening of Nigerian medicinal plants - Part II. Lloydia 41, 234.

7.Herbert, W. J. and Lumsden, W. H. R. (1976) Trypanosome brucei: a rapid "matching" method for estimating the host's parasitaemia. Exptal. Parasitol. 40: 427-431.

8.Bison P.J (2003) Preliminary studies of aqueous securidaca longipeduculata root extract in white albino rats, infected with $T . b$. brucei HND project submitted to the FCAH\&PT NVRI, VOM, Plateau State

9. Murray, M. (1979) Anaemia of bovine African Trypanosomiasis: An overview. In: pathogenecity of Trypanosomes eds. G. Losos and A. (choniard IDRC No 132 e, pp 121127.

10. ILCA (1986) The African Trypanotolerant network. Indications from results. 19831985

11. Anosa, V. O (1988) Haematological and Biochemical changes in Human and animal trypanosomiasis part II. Revue Elev. Med. Vet. Paystrop. 2:151-164.

12. Kaaya, G.P. Tizard, I. Maxie M., and Valli V. E.O (1980) Inhibition of leucopoiesis by sera from $T$. congolense. Tropenmed. Parasit. 31: 232-238. 